\title{
A EDUCAÇÃO NA RÚSSIA DE LÊNIN
}

\author{
Marisa Bittar ${ }^{1}$ \\ Universidade Federal de São Carlos (UFSCar) \\ bittar@ufscar.br \\ Amarilio Ferreira Jr. ${ }^{2}$ \\ Universidade Federal de São Carlos (UFSCar) \\ ferreira@ufscar.br
}

\section{Introdução}

A desintegração da União Soviética e a derrocada da sua experiência conhecida como "socialismo real", em 1991, não colocou fim apenas ao século XX, como bem definiu o historiador Eric Hobsbawm, mas provocou também o abandono de estudos críticos sobre aquela própria experiência, sobre os seus fundamentos, conquistas e erros. Com isso, Lênin (1870-1924), o fundador do Estado soviético e líder da revolução cujo objetivo era a construção do socialismo na Rússia, ficou estigmatizado e sua obra caiu no esquecimento. Anteriormente, mesmo quando os seus escritos eram considerados obrigatórios para a formação política da militância de esquerda, era mais comum a leitura de suas teses sobre a revolução, estratégia e tática para a construção da sociedade socialista. Poucos compreenderam, no entanto, que a estratégia da revolução não teria êxito sem uma política radical de instrução pública. Assim, com este texto, pretendemos contribuir para o conhecimento dessa face quase ignorada da ação revolucionária de Lênin e, para isso, basear-nos-emos em seus próprios escritos.

Na obra que Lênin escreveu após 1917 é flagrante a recorrência do tema sobre a instrução pública como política estratégica para o sucesso da revolução socialista. O discurso proferido no III Congresso da União Comunista da Juventude, em outubro de 1920, é o que melhor revela tal compreensão do líder bolchevique e por essa razão o reproduzimos na íntegra para a revista HISTEBR On-Line.

A Rússia começou a enfrentar o grave problema da instrução pública no momento em que reinava a ruína causada por dois trágicos acontecimentos: a Primeira Guerra Mundial (1914-1918) e a guerra civil (1918-1920) que se fez acompanhar pela invasão de forças armadas da Europa Ocidental, dos EUA e do Japão. A duríssima situação fora agravada pelo cerco hostil dos Estados capitalistas que haviam decretado o bloqueio econômico e o boicote político, desencadeando uma propaganda anti-soviética agressiva e ajudando a contra-revolução interna.

O discurso foi proferido nesse contexto, precisamente no ano em foi criada a Comissão Extraordinária da Rússia de Combate ao Analfabetismo e, nele, Lênin chama a atenção para o fato de que o socialismo teria de ser construído nas condições concretas existentes, sem ilusões e sem confiança exclusiva em palavras de ordem, as quais, por si sós, nada resolveriam. Ele conclama os jovens a estudarem com afinco tanto a teoria do socialismo quanto todo o pensamento anterior, ligando esses estudos ao trabalho prático pelo bem comum, expressão com a qual definia o comunismo. Para Lênin, essa construção não seria fácil, pois não poderiam empreendê-la com outra coisa que não fosse o material humano legado pelo capitalismo. Desse modo, segundo ele, tanto a intelectualidade burguesa precisaria ser vencida, transformada e reeducada, quanto os próprios proletários, a fim de se desembaraçarem de seus preconceitos pequeno-burgueses. Mas isso não 
ocorreria por milagre e, sim, por meio de uma luta prolongada para a qual a juventude exerceria papel fundamental.

A crítica à "velha escola" é um dos aspectos principais do discurso. Para Lênin, o socialismo deveria abolir tudo o que dela não servisse aos propósitos revolucionários, como o seu caráter classista e o método autoritário, aproveitando, porém, tudo o que dela fosse útil para a edificação de uma educação a serviço da construção do socialismo na Rússia soviética.

Em todas as ocasiões nas quais trata desse tema, ele o faz de modo a enfatizar a necessidade de uma reeducação com base nos princípios socialistas e de superação dos vícios da velha escola e da cultura pequeno-burguesa. Consultando os três tomos que compõem as suas Obras Escolhidas, isso fica evidente no terceiro, pois é ele que reúne os discursos, cartas, relatórios, artigos, e textos que ele elaborou após outubro de 1917, até a sua morte, inesperadamente ocorrida em janeiro de 1924. Nesse tomo, é possível encontrar, por exemplo, preciosas referências em $A$ doença infantil do esquerdismo no comunismo; no Relatório para o VIII Congresso dos Sovietes de toda a Rússia; no Relatório sobre a substituição das requisições pelo imposto em espécie; Sobre a cooperação, entre outras. Além disso, o Discurso na conferência de toda a Rússia dos Comitês de Instrução Política das secções de Gubérnia e Uezd da Instrução Pública é todo dedicado à discussão sobre a ligação da instrução com as tarefas políticas necessárias para a construção do socialismo e na qual Lênin assinala mais de uma vez que não podiam aceitar o velho ponto de vista da instrução apolítica e, conseqüentemente, não deveriam organizar o trabalho de instrução desligado da política. Esse texto, também de 1920, é particularmente importante por revelar a dificuldade enfrentada naquele momento quanto à resistência da organização dos professores à revolução socialista, o que Lênin classificou de "preconceitos burgueses". Faremos referências a essas e a outras publicações no decorrer deste texto.

No entanto, para os objetivos deste número especial da revista, vamos privilegiar o discurso proferido em outubro de 1920 para a União Comunista da Juventude da Rússia por ele abordar com maior abrangência a concepção de educação de Lênin e o enorme desafio que a instrução pública teria de enfrentar naquelas circunstâncias históricas. Adotamos o procedimento da reprodução integral do discurso, separadamente deste artigo, a fim de preservarmos a sua integridade, a sequiência dos argumentos e do raciocínio do autor e o seu estilo eloqüente, além de, com isso, facilitar a percepção da sua duração, isto é, quanto tempo transcorreu o contacto de Lênin com os jovens e a forma como foi recebido o discurso. De acordo com a publicação original, ele foi "acolhido com uma clamorosa ovação" e concluiu a palestra com "uma tempestade de aplausos", ocorrências que certamente se deveram à expectativa da juventude na revolução e ao próprio carisma político que caracterizava a sua pessoa. Optamos, portanto, por elaborar a análise separadamente do discurso, usando aspas para reproduzir trechos literais e adotando a grafia "Lênin" em vez de "Lenine", empregada em traduções portuguesas. A bibliografia relacionada ao final do texto, porém, segue esta última grafia pelo fato de as nossas fontes serem provenientes das obras traduzidas em português de Portugal.

\section{O discurso de Lênin no contexto de sua época}

Para uma melhor compreensão sobre as tarefas educacionais preconizadas por Lênin e sobre o que, efetivamente, deveriam ser as organizações da juventude numa república socialista, trataremos inicialmente do contexto histórico em que estavam inseridos o autor do discurso e os jovens a quem ele se dirigia. 
As palavras pronunciadas pelo líder da Revolução Russa de 1917 no III Congresso da União Comunista da Juventude, em outubro de 1920, traziam a marca da urgência histórica em defesa das transformações estruturais necessárias para a construção da sociedade socialista no contexto de uma conjuntura internacional adversa ${ }^{3}$. Além disso, estava condicionado também pelas consequiências da destruição humana e material que a intervenção armada, organizada por Inglaterra, França, Estados Unidos, Alemanha e Japão, antigos inimigos durante a Primeira Guerra Mundial (1914-1918), havia imposto à nascente Rússia Soviética por meio do chamado "cordão sanitário". Depois, com a vitória militar do Exército Vermelho ${ }^{5}$, o Partido Comunista da Rússia (bolchevique) aprovou no seu X Congresso, realizado em março de 1921, a Nova Política Econômica (NEP) como plano para superar o "comunismo de guerra" que havia vigido durante a guerra civil (19181920). Ao mesmo tempo, a NEP visava criar as condições da transição do capitalismo para o socialismo mediante a retomada do crescimento das forças produtivas ${ }^{6}$. Para Lênin, o sucesso da NEP era absolutamente fundamental e em vários discursos ele assinalou que sem o aumento da produção a revolução não venceria.

A NEP instituiu formas de capitalismo de Estado na primeira fase do processo de edificação do socialismo na Rússia Soviética. Pois, tratava-se de um plano econômico e político que visava fortalecer a organicidade da aliança entre o proletariado e o campesinato, que compunham a ampla parcela da população russa, por meio do restabelecimento da propriedade privada de determinados meios de produção e do livre comércio de mercadorias industriais e agrícolas destinadas ao consumo cotidiano ${ }^{7}$. Isso seria possível porque o Estado socialista detinha o controle da grande indústria, dos bancos, do transporte ferroviário e de navegação, do comércio exterior e da terra ${ }^{\mathbf{8}}$. Assim, a recuperação econômica da Rússia Soviética por meio das medidas adotadas pela NEP possibilitou criar as condições materiais e sociais elementares do processo inicial de construção do socialismo.

A partir de então, os desafios que se colocavam para o Estado socialista eram aqueles relacionados com a implementação das tarefas democrático-burguesas que ainda não haviam sido realizadas na Rússia, ou seja, as três outras "revoluções" que complementavam a Revolução de Outubro: industrial, agrária e cultural. Até 1861 prevaleciam na Rússia czarista as relações feudais de produção. A pátria de Tolstói era um dos países mais atrasados da Europa, onde os camponeses podiam ser vendidos e comprados como gado, como coisas. A passagem do agrarismo para o industrialismo, após 1917, tinha de superar ainda a destruição industrial que a Rússia soviética havia sofrido durante a guerra civil e a intervenção armada estrangeira. Portanto, era imperioso construir, com base em modernas técnicas, a chamada indústria pesada, a única capaz de impulsionar o desenvolvimento da indústria leve, reestruturar a agricultura, elevar o bem-estar do povo soviético e aumentar a capacidade de defesa militar do país. A base da industrialização passava pela edificação de uma série de ramos da moderna indústria pesada que não existiam na Rússia dos czares ou eram muito pouco desenvolvidas: siderurgia, construção de máquinas, de tratores, de tornos mecânicos, indústria automobilística, química, e outros. Mas, sem as fontes de energia para movimentar as fábricas, não seria possível implementar a moderna industrialização da Rússia Soviética?. Assim, teve início uma ampla mobilização da população para a construção de gigantescas hidrelétricas tanto na parte européia quanto asiática do território soviético ${ }^{\mathbf{1 0}}$. Energia elétrica e indústria de base, essas foram as duas primeiras grandes iniciativas de modernização econômica que arrancaram a Rússia Soviética do atraso imposto pelo agrarismo e, ao mesmo tempo, lançaram as bases da sociedade socialista. 


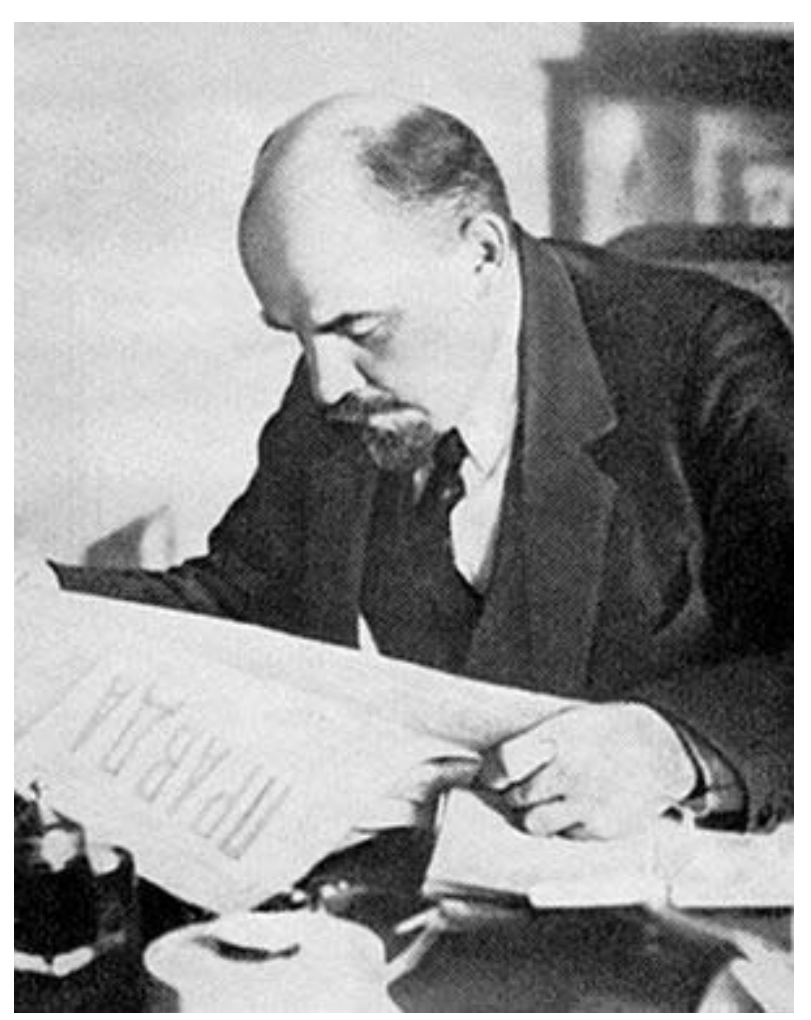

Lênin fazendo a leitura do jornal "Pravda”. Fonte: Nóvosti (1989).

Quanto ao processo de transformação da agricultura por meio da moderna técnica de produção, uma das primeiras medidas adotadas pelo Estado soviético foi a liquidação da propriedade latifundiária sobre a terra e o perdão das dívidas de 700 milhões de rublosouro, por ano, que os camponeses eram obrigados a pagar para os grandes proprietários pela compra ou arrendamento das terras ${ }^{11}$. Por outro lado, a necessidade de aumentar a produtividade agrícola, mediante o uso de técnicas produtivas fundadas em conhecimentos científicos e tecnológicos modernos ${ }^{\mathbf{1 2}}$, esbarrava na dispersão de recursos materiais e na tradição camponesa patriarcal que secularmente reinava nas aldeias do vasto império czarista $^{13}$. Premido pela demanda de erradicação da fome, o Estado Soviético implementou um acelerado processo de coletivização da agricultura, no qual operou a concentração das terras em grandes fazendas coletivas de agropecuária e a mecanização industrial da produção gerada. Além disso, promoveu uma ampla mobilização social pelo fim do analfabetismo e da formação técnica dos filhos dos camponeses.

Portanto, na esteira da construção econômica das bases materiais de sustentação da sociedade socialista, processava-se o desenvolvimento cultural dos povos que habitavam o imenso território soviético ${ }^{\mathbf{1 4}}$. Os primeiros resultados surgiram já nos anos que se seguiram ao fim da guerra civil. No domínio da instrução pública, por exemplo, a população alfabetizada cresceu de 32\%, em 1920, para 40\% nos fins de 1926. Nas aldeias funcionavam mais de 22 mil salas de aulas; o rádio e o cinema começaram a incorporar-se aos hábitos dos camponeses.

Foi neste contexto histórico que Lênin exortou a União da Juventude Comunista e se engajar nas tarefas de construção da sociedade socialista na Rússia Soviética. Para o líder bolchevique, a tarefa começava pela organização da nova escola de Estado e é essa face da sua atuação revolucionária, pouco conhecida da literatura da educação, que pretendemos realçar. 


\section{Lênin e a educação nos primeiros tempos da Rússia Soviética: anos que valeram séculos}

É possível que em nenhum país do mundo contemporâneo no começo do século XX a educação tivesse tomado a dimensão que tomou na Rússia Soviética, assumindo importância decisiva para a construção do socialismo. O entrelaçamento da educação com as condições materiais da sociedade, a necessidade do vínculo entre teoria e prática, segundo o princípio marxista, talvez nunca tenham estado tão claros quanto nesse período singular que foi o início da revolução bolchevique.

Lênin tinha tal convicção no papel estratégico da educação para o sucesso da revolução socialista que, como chefe máximo da revolução, posição equivalente a de presidente de um país, se empenhou pessoalmente para que no VIII Congresso do Partido Comunista (bolchevique), realizado em março de 1919, fosse aprovada a resolução que determinou: "1- Instrução geral e politécnica gratuita e obrigatória para todas as crianças e adolescentes dos dois sexos, até os 17 anos de idade; 2- Plena realização dos princípios da escola única do trabalho, com o ensino na língua materna, estudo em comum das crianças dos dois sexos, absolutamente laica, livre de qualquer influência religiosa, que concretize uma estrita ligação do ensino com o trabalho socialmente produtivo, que prepare membros plenamente desenvolvidos para a sociedade comunista" (apud MANACORDA, 1989, p. 314-315). Ou seja, a obrigatoriedade da escola em um país com índice de analfabetismo entre 90 e $95 \%{ }^{15}$, foi uma conquista diretamente ligada à atuação de Lênin.

No livro Lénine tel qu'íl fut, Anatóli Lounatcharski (1875-1933), chefe do Comissariado do Povo Para a Instrução, posição equivalente a de um ministro de Estado, e que conviveu intensamente com Lênin nos primeiros anos da revolução, confirma essa convicção sobre a imediata tarefa de elevar o nível cultural do povo a fim de que a revolução tivesse seqüência e sucesso. Ele enfatizou o seu constante otimismo assinalando que a audácia de Lênin ao fazer a revolução se devia à juventude de seu coração e que, por isso, ele morreu jovem aos 53 anos de idade.

Por acreditar na indissociabilidade entre os termos juventude e escola, fato que requeria uma instrução pública à altura da revolução e que se constituía em um dos maiores desafios a serem enfrentados, é que Lênin traçou as linhas mestras do seu pensamento a esse respeito no discurso que proferiu no Konsomol (União da Juventude Comunista). Segundo Lounatcharski, uma dessas linhas consistia em compreender a necessidade de evitar uma postura pretensiosa segundo a qual, para construir o socialismo seria suficiente o conhecimento ancorado nas palavras de ordem comunistas, descartando sumariamente a "ciência burguesa". Lênin insiste no grande erro que isso seria afirmando: "Não tenham medo de estudar!" (Lênin apud Lounatcharski, 1981, p. 133). Pois, estudando, os jovens comunistas ganhariam um saber enorme, indispensável, e saberiam julgar perfeitamente o que lhes conviria rejeitar. Tal atitude não significaria descartar o marxismo, ao contrário: "Se nós não assimilarmos toda a cultura do passado, não poderemos avançar" (Lênin apud Lounatcharski, 1981, p. 132) ${ }^{\mathbf{1 6}}$.

O discurso de Lênin foi didaticamente construído em torno de dois aspectos que consideramos entrelaçados: о que aprender e como aprender. Tal abordagem é surpreendente, pois essas duas ordens de preocupação parecem típicas e exclusivas de pedagogos. Lênin, contudo, via os dois aspectos que envolvem o conhecimento como um ato integral de forma e conteúdo, além de estabelecer uma relação inteiramente orgânica entre base material e educação, uma influenciando a outra e dependendo da outra.

Reportando-nos ao seu discurso, logo de início lemos que "a tarefa consiste em aprender”. É com essas palavras que Lênin começa a traçar as linhas da grande empreitada

Revista HISTEDBR On-line, Campinas, número especial, p. 377-396, abr2011 - ISSN: 1676-2584 
que a Rússia Soviética teria de enfrentar para construir o socialismo, tarefa muito mais complexa do que destruir as velhas bases da antiga sociedade baseada na exploração. Segundo ele, a geração de militantes criada naquela sociedade poderia, quando muito, destruir seus alicerces, mas teria de instruir-se plenamente a si própria para edificar a nova sociedade, sem exploração do homem pelo homem.

Mas aprender o quê? Essa é a primeira ordem de questões levantadas por Lênin. Expondo de forma clara o seu pensamento, propõe a reflexão segundo a qual a tarefa de continuar a revolução que os sovietes haviam começado só poderia ser continuada pelos jovens comunistas se eles próprios se dispusessem a aprender em que consiste o comunismo. Nas palavras de Lênin, "toda a juventude em geral que queira passar ao comunismo tem de aprender o comunismo". O que ele frisa em todo o seu discurso é a idéia segundo a qual não basta declarar-se comunista: é necessário compreender os seus princípios e praticá-los. No entanto, enganar-se-ia quem, apressadamente, acreditasse que essa fosse uma tarefa simples. Lênin é categórico ao desfazer essa ilusão, afirmando que ninguém se tornaria um verdadeiro comunista nutrindo-se apenas de palavras de ordem, o que, aliás, seria perigoso. Por isso, assinala: "Deveis educar-vos para serdes comunista". Ele insiste em que a formação intelectual demandaria esforço próprio para compreender os desafios da nova situação, combinando teoria e capacidade de intervenção prática. Os princípios, segundo ele, se fossem desvinculados da compreensão sobre a situação em que se encontrava a Rússia naquele momento, de nada serviriam "porque prolongariam o antigo divórcio entre a teoria e a prática", o "mais repugnante traço da velha sociedade", como podemos ler:

\footnotetext{
"Por isso seria extremamente incorrecta a simples assimilação livresca daquilo que dizem os livros sobre o comunismo. Os nossos discursos e artigos de agora não são uma simples repetição daquilo que se disse antes sobre o comunismo, pois os nossos discursos e artigos estão ligados ao nosso trabalho quotidiano e multilateral. Sem trabalho, sem luta, o conhecimento livresco do comunismo, adquirido em brochuras e obras comunistas, não vale absolutamente nada, porque prolongaria o antigo divórcio entre a teoria e a prática, esse antigo divórcio que constituía o mais repugnante traço da velha sociedade burguesa" (LENINE, 1980, p. 387).
}

Inicialmente, pois, destacamos a importância do discurso no que concerne à necessidade imperiosa, para aqueles que deveriam continuar a obra revolucionária de 1917, de ampliar a sua própria instrução e de reeducar-se. Lênin chega a empregar o adjetivo "fanfarrão" para designar quem negligenciasse tal formação e expressa constantemente essa preocupação naqueles difíceis anos. É possível percebê-la em outros discursos e textos seus, como na Saudação aos operários húngaros, de 1919, quando afirmou que o poder do proletariado deveria ser "apoiado em todas as conquistas da cultura, da ciência e da técnica do capitalismo" (LENINE, 1980, p. 135).

Ao apelar para a necessidade de cada jovem que se dizia comunista tornar-se de fato um comunista, estabelecendo a ligação entre a teoria e a prática, Lênin nos faz lembrar da advertência de Engels, em carta de 5 de agosto de 1890, aos jovens escritores alemães que se apropriavam de frases suas e de Marx sem o devido estudo da história, como era o caso do uso da expressão "materialista", empregada de modo a "fazer boa figura". Criticando tal postura, assim escreveu: 


\begin{abstract}
"De modo geral, a palavra 'materialista' na Alemanha, constitui para muitos escritores jovens apenas uma frase que ajuda a classificar, sem necessidade de maior estudo, tudo o que houve e tudo o que está por acontecer; cola-se este rótulo e acredita-se que se pode dar o assunto por encerrado. No entanto nossa concepção da história é, antes de tudo, um guia para o estudo e não uma alavanca destinada a erguer construções à maneira hegeliana. É necessário estudar novamente toda a história, - e estudar, em suas minúcias, as condições de vida das diversas formações sociais - antes de fazer derivar delas as idéias políticas, estéticas, filosóficas, religiosas, sobre o direito privado, etc, que lhes correspondem. Até hoje, tem-se feito muito pouco nesse terreno; pois tem sido muito reduzido o número de pessoas que se dedicaram a isso. (...) Em vez de fazer isso, porém, para um número considerável de alemães mais jovens, a frase do materialismo histórico (tudo pode ser convertido em frases) só serve para construir, às pressas, a partir de seus conhecimentos históricos, relativamente escassos (...) todo um sistema e fazer boa figura" (ENGELS, 1965, p. 416) ${ }^{17}$.
\end{abstract}

A preocupação de Engels com a necessidade de estudos minuciosos sobre as condições de vida das diversas formações sociais é a mesma que Lênin demonstra ter no momento em que era indispensável conhecer as condições concretas da Rússia soviética para, dessas mesmas condições, estabelecer as tarefas práticas da nova educação em vez de simplesmente os jovens se escudarem em palavras de ordem que não correspondessem às condições reais existentes.

Empregando o princípio dialético segundo o qual o novo nasce do velho, indaga Lênin a certo instante: "Que é que devemos tomar da velha escola, da velha ciência?" Para sabê-lo, ele começa a desnudar o caráter da velha escola, que, contrariamente aos propósitos proclamados, sendo classista, destinava aos camponeses e operários apenas treinamento, rudimentos para o trabalho, enquanto aos filhos da burguesia, o conhecimento desinteressado."Por isso, ao rejeitar a velha escola, propusemo-nos a tarefa de tomar dela apenas aquilo que nos é necessário para conseguir uma verdadeira formação comunista". Prosseguindo no exame sobre os seus defeitos, Lênin assinala que ela era uma escola de estudo livresco, de "amestramento" e aprendizagem de cor. O estudo livresco, de acordo com ele, "obrigava as pessoas a assimilar uma quantidade de conhecimentos inúteis, supérfluos, mortos", que talhavam a jovem geração "pela mesma medida". No entanto, se disso concluíssem ser possível tornar-se comunista "sem ter assimilado os conhecimentos acumulados pela humanidade", os jovens da União Comunista da Rússia cometeriam "um enorme erro", pois não lhes bastaria "assimilar as palavras de ordem comunistas, as conclusões da ciência comunista, sem assimilar a soma de conhecimentos de que o comunismo é conseqüência" (LENINE, 1980, p. 388). Em seguida, cita o marxismo como um exemplo de como o comunismo surgiu da soma dos conhecimentos humanos. Pois Marx, segundo ele, assimilou tudo o que a ciência anterior havia formulado, reelaborando de modo crítico o que o pensamento humano havia criado, retirando daí as conclusões que o pensamento limitado ao quadro burguês não podia retirar.

Estabelecendo o elo entre a educação e a base material da sociedade russa nos primeiros anos da revolução e assim elaborando uma análise fidedigna ao método de Marx, Lênin indica que, dentre tantos, o maior desafio para aumentar a produtividade do trabalho como condição necessária para o sucesso do socialismo, era, sem dúvida nenhuma, a eletricidade. Isso porque, "a seguir às tarefas militares, às tarefas da defesa da república, se coloca perante nós a tarefa económica". Ou seja, seria impossível edificar a sociedade 
comunista sem restaurar a indústria e a agricultura. Mas, "é preciso restaurá-las não à maneira antiga: É preciso restaurá-las sobre uma base moderna, segundo a última palavra da ciência", adverte Lênin. Essa base era a eletricidade e "só quando todo o país, todos os ramos da indústria e da agricultura estiverem electrificados, quando realizardes essa tarefa, só então podereis edificar para vós mesmos a sociedade comunista que a velha geração não poderá edificar. Coloca-se perante vós a tarefa do renascimento tanto da agricultura como da indústria sobre uma base técnica moderna, que assente na ciência e na técnica modernas, na electricidade". Portanto, a eletrificação de todo o sistema produtivo russo, para Lênin, era o primeiro degrau importante no caminho para a organização comunista da vida econômica, tarefa que não levaria menos que dez anos. Tirar a Rússia da escuridão era a sua obsessão. Ele dizia que nenhum comunista podia encarar com naturalidade o fato de que os camponeses e operários tivessem vivido séculos na escuridão, na miséria, e que, apesar disso, não seria possível sair depressa da escuridão; no entanto, tinham de conseguir já naquele momento que cada central elétrica construída por eles se transformasse realmente numa base de instrução, que se dedicasse, "por assim dizer, à educação elétrica das massas" (LENINE, 1980, p. 430). A esse respeito, em fevereiro de 1920, em uma conversa com o correspondente do jornal americano The World, Lincoln Eire, ele supôs que:

“(...) dentro de três anos estarão acesas, na Rússia, 50.000.000 de lâmpadas incandescentes. Suponho que nos Estados Unidos há 70.000.000 dessas lâmpadas, mas para um país onde a eletricidade se encontra ainda na infância, mas de dois terços desse número representam um enorme progresso. Em minha opinião, a eletrificação é a mais importante das grandes tarefas que se nos colocam”. (LENINE, 1980, p. 257)

A urgente eletrificação de toda a Rússia é considerada no discurso de Lênin como um exemplo prático de como os jovens deveriam aprender, já que o princípio básico da sua exposição foi o da necessidade de apropriação da soma de conhecimentos humanos de tal modo que o comunismo não fosse para eles algo aprendido de memória, mas pensado por eles mesmos, "uma conclusão necessária do ponto de vista da educação moderna". Ao mesmo tempo, esse exemplo era perfeito para demonstrar aos jovens a necessidade de vincularem estudo ao trabalho prático. Para explicar-lhes isso, Lênin (1980, p. 390) começa alertando para o fato de que tal tarefa não poderia ser obra de analfabetos:

\footnotetext{
"Compreendeis perfeitamente que a electrificação não pode ser obra de analfabetos e que aqui não basta uma instrução elementar. Aqui não basta compreender o que é a electricidade: é preciso saber como aplicá-la tecnicamente à indústria, à agricultura e a cada um dos ramos da indústria e da agricultura. Tudo isso temos que aprendê-lo nós próprios, e devemos ensiná-lo a toda a jovem geração trabalhadora. Esta é a tarefa que se coloca a cada comunista consciente, a cada jovem que se considera comunista e que se dá claramente conta de que, ao ingressar na União Comunista da Juventude, assumiu a tarefa de ajudar o partido a edificar o comunismo e de ajudar toda a jovem geração a criar a sociedade comunista. Ele deve compreender que só sobre a base da educação moderna a poderá criar, e que se não possuir essa educação o comunismo continuará a ser apenas um desejo" (grifo nosso).
}

Chamamos a atenção aqui para a expressão "educação moderna", empregada no discurso, o que nos remete a uma referência de Mario Alighiero Manacorda em seu livro 
História da educação. Ao tratar da Escola Nova, o autor menciona que também na União Soviética foram realizadas experiências semelhantes e afirma que Blonskij, Krupskaia e outros nomes marcaram grande estação do ativismo pedagógico soviético. O próprio Lênin, segundo Manacorda, ouvindo o testemunho de um emigrante russo sobre as experiências americanas, teria se dirigido a Krupskaia com essas palavras: "É preciso estudar minuciosamente a experiência americana, é preciso fazer nosso tudo aquilo que se conseguiu nos países capitalistas, avaliá-lo com base no critério da nossa posição marxista e ver o que nos convém e o que não nos convém" (apud Manacorda, 1989, p. 313). No entanto, aqui não nos é possível averiguar com profundidade esse aspecto por falta de referências mais explícitas de Lênin, embora, no seu discurso, quando menciona a "educação moderna", o sentido que ele lhe dá não nos parece ser exclusivamente o de rejeição à velha escola.

Retomando os dois aspectos que nos propusemos analisar (o que aprender e como aprender), sublinhamos a crítica contundente ao apego às palavras de ordem comunistas, ocasião em que Lênin aproveita para alertar os jovens para não as tomarem como suficientes para a sua formação. Esse aspecto relativo ao que aprender nos parece fundamental se levarmos em conta as práticas que redundaram, depois, em "revoluções culturais" levadas a cabo pelas sociedades do "socialismo real", que instauraram uma estética e uma compreensão da cultura sectárias e autoritárias, enquanto nos discursos de Lênin dessa época, notamos a preocupação em se conhecer a cultura, a ciência, todo o pensamento anterior ao marxismo, inclusive como procedimento para melhor compreender o próprio marxismo. Por essa razão, ele insiste em que todo jovem que se dizia comunista tinha obrigação de nutrir-se de todos os conhecimentos elaborados pela "ciência burguesa" superando-os, pois se a tarefa era edificar a sociedade comunista, eles só poderiam "cumpri-la possuindo todos os conhecimentos modernos, sabendo transformar o comunismo de fórmulas, conselhos, receitas, prescrições e programas já feitos e aprendidos de cor em algo de vivo que dá unidade ao vosso trabalho imediato, transformar o comunismo em guia do vosso trabalho prático".

Quanto ao segundo aspecto do discurso, isto é, o relativo ao "como é preciso aprender", na perspectiva da construção do socialismo, segundo Lênin, "só ligando indissoluvelmente cada passo da actividade na escola, cada passo da educação, da formação e do ensino à luta de todos os trabalhadores contra os exploradores". Com base nessa premissa, ele se dispõe a mostrar aos jovens, por meio de exemplos extraídos da experiência do trabalho desta ou daquela organização da juventude, como se deveria fazer essa "educação do comunismo". O primeiro exemplo foi o da necessidade de fazer com que cada analfabeto da Rússia soviética lesse e escrevesse. "Todos falam de liquidar o analfabetismo. Sabeis que num país analfabeto é impossível edificar a sociedade comunista", afirma Lênin. Mas, para isso, não bastaria que o poder Soviético desse uma ordem, ou que lançasse mão dos melhores militantes nessa tarefa. A tarefa de transformar a Rússia de um país ignorante e analfabeto num país instruído, seria impossível de concretizar rapidamente e exigia que toda a jovem geração pusesse, ela mesma, mãos à obra. Lênin conclama: "O comunismo consiste em que a juventude, os rapazes e raparigas que constituem a União da Juventude digam: essa é a nossa causa, unir-nos-emos e iremos para o campo para liquidar o analfabetismo, para que a nossa jovem geração não tenha analfabetos". Para ele, somente se a União da Juventude se empenhasse nisso, se toda a juventude trabalhasse em proveito de todos, ela teria o direito de se chamar União Comunista da Juventude: 


\begin{abstract}
"A tarefa da União consiste ainda em, ao assimilar um ou outro conhecimento, ajudar a juventude que não pode libertar-se por si mesma das trevas do analfabetismo. Ser membro da União da Juventude significa consagrar o seu trabalho, as suas forças, à causa comum. Nisto é que consiste a educação comunista. Só neste trabalho um rapaz ou uma rapariga se converterá num verdadeiro comunista. Só se tornarão comunistas se conseguirem alcançar êxitos práticos com este trabalho" (LENINE, 1980, p. 396).
\end{abstract}

Sobre o enorme desafio e as dificuldades de toda ordem, Lounatcharski (1981, p. 129) realça que, apesar de a luta contra o analfabetismo ter se ressentido da fome de 1921, Lênin repetia que era um dever imediato erradicá-lo, especialmente na população com até 35 anos de idade, quando comemorassem o décimo aniversário da revolução. A luta pela educação não devia restringir-se à instrução primária, mas à erradicação do analfabetismo e à política de bibliotecas públicas.

O interesse pessoal de Lênin nessa tarefa estratégica foi mostrado por Manacorda, com uma transcrição que fez sobre um diálogo entre ele e um menino, seu conhecido, de doze anos, que começou com a pergunta: "Que tarefas tiveste, e qual foi a aula?". O menino respondeu: "Tivemos três horas". "E quais?" "Matemática". "E depois?" "Depois, história". "E que história?" "Do Egito"."E depois?" "E depois, língua alemã”. Lênin, então, começou a rir e disse para sua esposa, a pedagoga Krupskaia: "Tudo é ainda como antes" (MANACORDA, 1989, p. 315). Ou seja, enquanto o país começava uma revolução de caráter socialista, a escola ainda privilegiava o ensino de história do Egito e da língua alemã, em detrimento da sua própria, além de consagrar apenas três horas aos estudos, o que, certamente, se devia à escassez de vagas para todas as crianças.

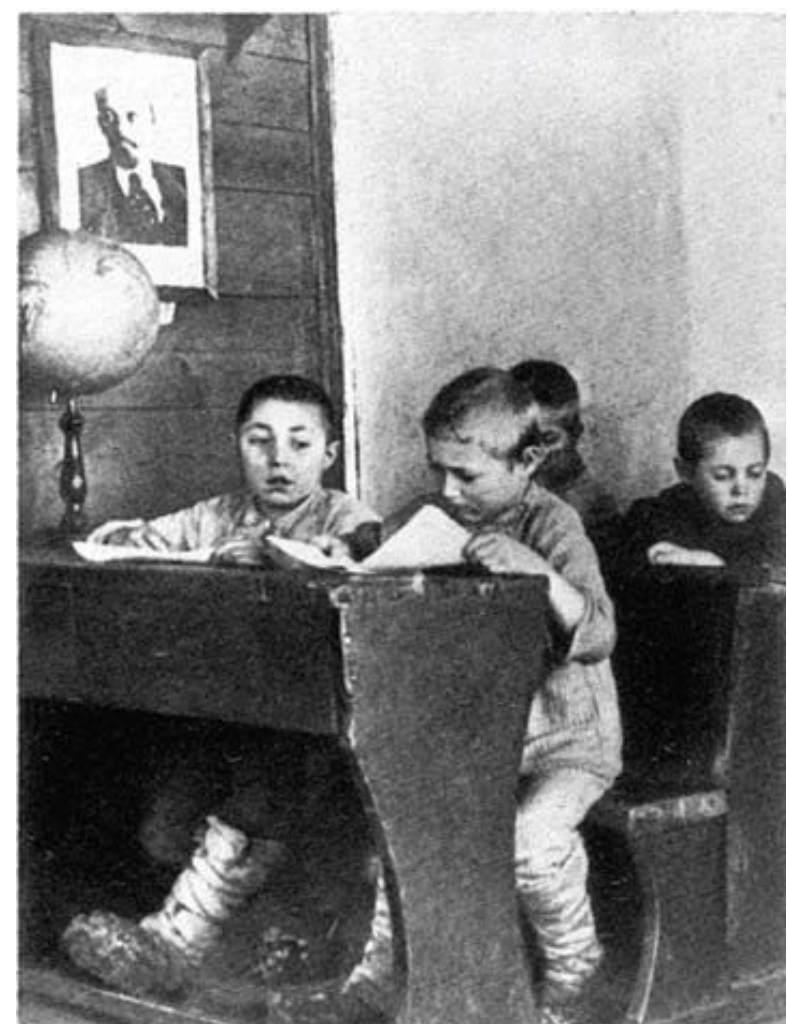

Crianças soviéticas na escola elementar depois da Revolução. Duas particularidades chamam atenção: o pé enfaixado do menino, recurso comum entre camponeses que não tinham calçados para enfrentar o inverno e a fotografia de Lênin no alto da parede. Fonte: Nóvosti (1989). 
Além do exemplo da luta contra o analfabetismo, Lênin menciona o trabalho nas hortas suburbanas. "Não será esse um trabalho útil?". E responde afirmativamente que essa, sem dúvida, era uma das indispensáveis tarefas da União Comunista da Juventude. "O povo passa fome, há fome nas fábricas. Para nos livrarmos da fome é preciso desenvolver as hortas, mas a agricultura continua a fazer-se à antiga. É preciso que os elementos mais conscientes ponham mãos à obra, e então vereis aumentar o número de hortas, aumentar a sua superfície e melhorar os resultados" (LENINE, 1980, p. 396). Portanto, a União Comunista da Juventude deveria participar ativamente delas considerando-as como sua tarefa.

Lênin, todavia, exige mais dos jovens. Ele pede que a União Comunista da Juventude se converta em "um grupo de choque que em qualquer trabalho dá a sua ajuda e manifesta a sua iniciativa e espírito empreendedor". Sem meias-palavras, assinala: "Se a União Comunista da Juventude não souber organizar assim o seu trabalho em todos os domínios, isso significa que se desvia para o antigo caminho burguês". Unir a educação à luta dos trabalhadores contra os exploradores era indispensável para a construção do socialismo e, para isso, os membros da União deveriam "consagrar todas as suas horas livres a melhorar as hortas, ou a organizar em qualquer fábrica a instrução da juventude, etc". Para transformar a Rússia de um país pobre e miserável num país rico era necessário que a União Comunista da Juventude unisse a sua formação, o seu ensino e a sua educação ao trabalho dos operários e dos camponeses, "que não se feche nas suas escolas nem se limite a ler livros e brochuras comunistas" (grifo nosso). Não se fechar em suas escolas significava claramente unir o estudo ao trabalho prático de construção da sociedade socialista (aspecto do discurso ligado ao como aprender). Não se limitar a ler livros e brochuras comunistas significava ampliar e aprofundar os conhecimentos (aspecto do discurso ligado ao que aprender). Lênin conclui suas palavras lembrando que na sociedade capitalista cada um trabalhava só para si, não se preocupando se havia velhos ou doentes "ou se todos os trabalhos da casa recaíam sobre os ombros da mulher, que se encontrava, por isso, oprimida e escravizada". Em seguida, pergunta e deixa a resposta implícita: "Quem tem o dever de lutar contra isso?" (LENINE, 1980, p. 396).

O empenho de Lênin para criar uma prática de trabalho coletivo na Rússia soviética foi marcante. Sobre esse tema escreveu Uma grande iniciativa tratando dos "sábados comunistas" criados pelos operários, em 1919, fato que o encheu de entusiasmo. Para ele, essa grande iniciativa era apenas um começo, mas um começo de excepcional importância. "É o começo de uma revolução mais difícil, mais essencial, mais radical e mais decisiva do que o derrubamento da burguesia, pois é uma vitória sobre a própria rotina, o desleixo, o egoísmo pequeno-burguês, sobre todos esses hábitos que o maldito capitalismo deixou em herança ao operário e ao camponês. Quando esta vitória estiver consolidada, então e só então se criará a nova disciplina social, a disciplina socialista, então e só então será impossível voltar para trás, para o capitalismo, e o comunismo se tornará verdadeiramente invencível". (LENINE, 1980, p. 143).

A ênfase dispensada pelo líder bolchevique à união entre teoria e prática como um aspecto central da educação comunista estava em sintonia com a crítica que Marx e Engels haviam elaborado no século anterior. Na obra $\boldsymbol{A}$ ideologia alemã, por exemplo, eles rejeitaram a concepção de história até então hegemônica advertindo para a necessidade de uma ação calcada no desvelamento das contradições da sociedade capitalista (crítica à ideologia), enfatizando que a história não podia ser uma coleção de fatos sem vida, como a apresentavam os empiristas, nem ação imaginária de sujeitos imaginários, como a apresentavam os idealistas. Era necessário superar ambas as visões. E sem o estudo e a 
compreensão sobre o funcionamento da própria sociedade, isso não seria possível. Mais explícito foi Marx na $11^{\mathrm{a}}$ tese sobre Feuerbach, afirmando que os filósofos, até então, haviam se limitado a interpretar o mundo de maneiras diferentes, desconsiderando a necessidade de transformá-lo. Ao elaborar essa tese, Marx não disse, porém, que não mais caberia interpretar o mundo e, sim, que não era suficiente interpretá-lo. Esse princípio nos parece presente no discurso de Lênin, para quem, estudar, conhecer o pensamento burguês, assimilá-lo numa perspectiva crítica (superá-lo, portanto), assim como estudar a fundo os clássicos do marxismo, mas não se restringir a isso, deveria ser a postura de todo jovem que se auto-intitulasse comunista. Conhecer, analisar as condições concretas da Rússia para, então, munido desses conhecimentos, transformar a sociedade russa rumo ao comunismo: eis o que nos parece ser a síntese, a preocupação central demonstrada por Lênin. Ou seja, interpretar e transformar.

Como metódico estudioso da obra de Marx e de Engels, o conhecimento de Lênin sobre a concepção de educação dos dois autores fica evidente em seus discursos, cartas e relatórios. Marx e Engels (1982, p. 125), formularam tal concepção começando com o Manifesto do Partido Comunista (1848), em que escreveram: "Ensino público e gratuito para todas as crianças. Abolição do trabalho das crianças nas fábricas sob a sua forma atual. Unificação do ensino com a produção material". Depois, As Instruçães aos delegados (1866-1867) que, nos primeiros dias de setembro de 1866, Marx entregou aos delegados do comitê provisório de Londres ao I Congresso da Associação Internacional de Trabalhadores (realizada em Genebra) estabeleceu o seguinte:

"Por ensino compreendemos três coisas: Primeiro, ensino intelectual. Segundo: educação física, dada nas aulas de ginástica e por meio de exercícios militares. Terceiro: adestramento tecnológico que transmita os fundamentos científicos gerais de todos os processos de produção e que, ao mesmo tempo, introduzirá a criança e o adolescente no uso prático e na capacidade de manter os instrumentos elementares de todos os ofícios" (Marx, 1982, p. 83-84).

Quase simultaneamente às Instruções, escreveu Marx (1984, v. I, p.554) em sua obra principal, $\boldsymbol{O}$ Capital: "Do sistema da fábrica (...) nasceu o germe do ensino futuro que unirá para todas as crianças, a partir de uma certa idade, o trabalho produtivo com o ensino e a ginástica (...) para produzir homens plenamente desenvolvidos". Nas duas obras nota-se a valorização deste ensino como superior a todo tipo histórico de ensino que existiu e que colocaria a classe operária acima das classes dominantes existentes (Instruções) e produziria homens plenamente desenvolvidos ( $\boldsymbol{O}$ Capital $)$. Para Lênin, profundo conhecedor dessas obras, a idéia fundamental da união do ensino com o trabalho produtivo consistia no apoio firme da pedagogia marxista. Nessa breve alusão à concepção de Marx e de Engels sobre educação, voltamos a citar $\boldsymbol{A}$ ideologia alemã , obra na qual se lê que, em contraposição à atuação de cada indivíduo em uma esfera de atividade exclusiva, típica da divisão social do trabalho no capitalismo:

\footnotetext{
"na sociedade comunista, porém, onde cada indivíduo pode aperfeiçoarse no campo que lhe aprouver, não tendo por isso uma esfera de atividade exclusiva, é a sociedade que regula a produção geral e me possibilita fazer hoje uma coisa, amanhã outra, caçar de manhã, pescar à tarde, pastorear à noite, fazer crítica depois da refeição, e tudo isso a meu belprazer, sem por isso me tornar exclusivamente caçador, pescador ou crítico. Essa petrificação do nosso próprio trabalho num poder objetivo
} 
que nos domina e escapa ao nosso controle contrariando a nossa expectativa é um dos momentos capitais do desenvolvimento histórico até aos nossos dias" (MARX; ENGELS, 1980, p. 41).

O princípio da formação completa, pois, já estava esboçado nessa obra de 1845 com a qual os dois autores criticaram o combate filosófico travado entre os jovens hegelianos contra as sombras da realidade, e não contra a própria realidade. Quando escreveu A doença infantil do esquerdismo no comunismo, combatendo o argumento de que os comunistas não deveriam atuar em sindicatos "reacionários", que deveriam se recusar a este trabalho e criar uma nova união operária "muito novinha, muito limpinha, inventada por comunistas muito simpáticos (e na maioria dos casos, provavelmente muito jovens) etc, etc". (LENINE, 1980, p. 299), Lênin provavelmente tinha em mente essas obras que foram fundamentais para a sua formação, por isso, enfatizou que o capitalismo legava inevitavelmente ao socialismo, por um lado, as velhas diferenças profissionais formadas ao longo dos séculos, e, por outro lado, os sindicatos, que só muito lentamente poderiam se transformar em sindicatos de indústrias mais amplos, menos corporativos. Depois, "através desses sindicatos de indústria, passar-se-á à supressão da divisão do trabalho entre os homens, à educação, ensino e preparação de homens universalmente desenvolvidos e universalmente preparados, homens que saberão fazer tudo" (LENINE, 1980, p. 299). Tentar antecipar-se na prática a esse resultado futuro seria o mesmo que querer ensinar matemática superior a uma criança de quatro anos. Os comunistas, portanto, não deviam temer esse "reacionarismo", pois isso equivaleria a duvidar de sua própria capacidade de "instruir, ilustrar, educar, atrair a uma nova vida as camadas mais atrasadas" (LENINE, 1980, p. 300). Ou seja, para se chegar ao patamar de uma educação omnilateral,

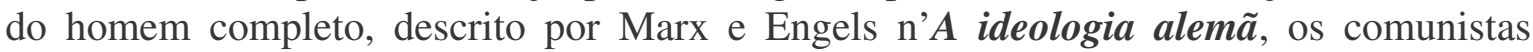
teriam de atuar com a herança do capitalismo. "Devemos começar a construir o socialismo não com um material humano fantástico nem especialmente criado por nós, mas com o que nos legou o capitalismo", insiste Lênin. Dizer que isso seria muito difícil era proibido e qualquer outra abordagem do problema não merecia ser levada em conta.

Discursando com seu habitual otimismo na revolução, Lênin não deixava de repetir, como se vê, que a tarefa não seria nem fácil nem rápida. No entanto, teria de ser iniciada. A propósito, em 1921, ao discursar no X Congresso do Partido Comunista da Rússia (bolchevique) voltou ao ponto, enfatizando que toda a obra de transformação do pequeno agricultor, "da transformação de toda a sua psicologia e de todos os seus hábitos, é obra de várias gerações. Só a base material, a técnica, a utilização em grande escala de tratores e máquinas na agricultura, a eletrificação em grande escala, podem resolver este problema em relação ao pequeno agricultor. Se eu digo que são necessárias gerações, isto não significa que sejam necessários séculos". (LENINE, 1980, p. 476). A perspectiva do amanhã e a necessidade do trabalho de todos para a construção do futuro que começou em outubro de 1917 é o fator que explica por que a Rússia chegou alfabetizada e eletrificada às vésperas da hecatombe de 1939.

Para uma idéia mais precisa do que isso significou lembremos que na Rússia czarista, na encruzilhada dos séculos XIX e XX, sete em cada dez habitantes (sem contar as crianças com menos de nove anos de idade) não sabiam ler nem escrever. Na Ásia Central, no Norte da Sibéria e em certas regiões orientais dos confins do imenso império, a situação era ainda pior: nove em cada dez habitantes eram analfabetos. Apesar desse quadro desolador, entre 1800 e 1913, os institutos pedagógicos da Rússia formaram apenas seis mil pessoas. Em 1917, a formação de pedagogos aumentou, mas mesmo assim os respectivos estabelecimentos de ensino só proporcionavam no máximo $25 \%$ dos 
professores de que necessitava o país. Em 1906, a revista Boletim de Educação, editada pelo Ministério da Educação czarista fizera a seguinte estimativa: "na parte européia da Rússia, toda a população só poderia ser alfabetizada dentro de 120 anos; na Sibéria e no Cáucaso, dentro de 430 anos; na Ásia Central, dentro de 4600”"18.

O sistema de ensino secundário na Rússia czarista, por sua vez, era heterogêneo. Além de ginásios, onde predominava o ensino de humanidades e línguas antigas, existiam escolas de ensino profissional nas quais se dava preferência a matéria das Ciências Naturais, Matemática e disciplinas técnicas. Existiam, ainda, institutos para moças nobres, corpos de cadetes e outros estabelecimentos de ensino para as elites que, além de conhecimentos, aprendiam as maneiras aristocráticas.Além do curso secundário completo que proporcionava uma preparação geral bastante sólida, embora um tanto unilateral, existiam escolas primárias sem continuidade com as secundárias: as eclesiástico-paroquiais e as destinadas principalmente a filhos de operários e camponeses, chamadas "zemstvos". Supunha-se que ao povo bastavam apenas conhecimentos elementares, como ler, escrever e fazer contas simples. Terminado o primário, formalmente não se proibia realizar o secundário, mas na prática neste caminho interpunham-se barreiras quase intransponíveis. Na Rússia de 1913, com uma população de 160 milhões de habitantes, havia apenas 434 ginásios e 276 escolas profissionais, todos eles freqüentados por apenas 160 mil crianças e adolescentes. Em 1915, apenas 8 milhões de crianças freqüentavam a $1^{\mathrm{a}}, 2^{\mathrm{a}}$ e $3^{\mathrm{a}}$ classes do ensino primário; e apenas 948 mil chegavam à $4^{\text {a }}$ classe.

Em 1920, ano do discurso de Lênin, todos os flagelos se abatiam sobre o país: fome, frio, desemprego, inflação. Para uma população de 160 milhões de habitantes, faltavam víveres, combustível, artigos manufaturados de primeira necessidade começando por fósforos e terminando por roupa. Nesse quadro de penúria, às vezes os alunos escreviam com carvão vegetal ou tinta feita de fuligem. Para escrever e imprimir livros, serviam-se de papel de embrulho; como não havia cartilhas, aprendiam a ler soletrando textos de jornais ou revistas. Como faltavam professores, as suas funções ficavam a cargo de ajudantes voluntários que, muitas vezes, tinham aprendido a ler e a escrever havia pouco tempo. Assim começou a obra que exigiu esforços incansáveis e um dos resultados mais impressionantes foi que "de 1923 a 1939, na União Soviética aprenderam a ler e a escrever mais de 50 milhões de analfabetos e cerca de 40 milhões de semi-analfabetos" ${ }^{\text {"19 }}$.

Cabe acrescentar, ainda, que o sucesso da revolução socialista e, por conseguinte, da implementação de suas tarefas educacionais se deveram também às tomadas de decisões políticas centralizadas pela direção partidária bolchevique. A prática da ação política centralizada remontava a 1903, quando o Partido Operário Social-Democrático Russo (POSDR), o partido dos marxistas, sofreu uma cisão entre "bolcheviques" (que em russo, significa maioria) e "mencheviques" (minoria). Liderando os primeiros estava Lênin, enquanto Martov capitaneava os segundos. A divergência política estava relacionada ao caráter que a organização estatutária do partido deveria assumir: os leninistas defendiam a estrutura centralizada e os martovianos a descentralizada ${ }^{20}$. Segundo Lênin, só um partido fortemente organizado e centralizado poderia liderar uma revolução socialista na Rússia. A sua tese venceu e, a partir daí, o partido inscreveu em sua nomenclatura o termo "bolchevique" 21 contra a tese derrotada dos mencheviques. Ocorre, porém, que a tática necessária para o partido liderar a revolução foi, depois, transposta para a sua relação com a sociedade soviética, ou seja, o centralismo, que era um princípio interno ao partido, aceito e praticado pelos seus membros, passou a ser imposto do partido para o conjunto da sociedade como uma medida para consolidar a revolução. A propósito, Hobsbawm sustenta que, ante todas as vicissitudes, a revolução sobreviveu devido a três grandes razões. A primeira foi exatamente porque a revolução "possuía um instrumento de poder 
único, praticamente construtor do Estado, no centralizado e disciplinado Partido Comunista de 600 mil membros. Qualquer que tenha sido seu papel antes da Revolução, esse modelo organizacional, incansavelmente propagado e defendido por Lênin desde 1902, atingiu a maioridade depois dela". (HOBSBAWM, 1995, p. 71). A segunda razão foi o fato de o governo bolchevique ser o único capaz de manter a Rússia integral como Estado; e a terceira consistia em que só a Revolução permitiu ao campesinato tomar a terra, o que deu aos bolcheviques uma vantagem decisiva na Guerra Civil de 1918-20. Para aquilatarmos a dimensão do centralismo do Partido Comunista lembremos que o próprio Lênin afirmava que os comunistas, ante toda a sociedade russa da época, não eram mais que uma gota no mar. Como teriam, então, conseguido manter a revolução?

\section{Conclusão}

Ao concluirmos esta análise, não é nosso propósito elaborar um balanço da educação na Rússia Soviética, pois o fim do "socialismo real", em 1991, ultrapassa em muito o limite temporal da época em que viveu Lênin. De todo modo, não podemos deixar de mencionar que a alfabetização e a eletrificação do país, duas metas essenciais abordadas no discurso para a União da Juventude Comunista, em 1920, foram plenamente alcançadas antes que um outro acontecimento trágico da história abatesse o país: a Segunda Guerra Mundial (1939-1945), que tirou a vida de vinte e cinco milhões de soviéticos. A campanha de alfabetização por essa época já estava vitoriosa na União das Repúblicas Socialistas Soviéticas (URSS) e isso em um país que contava com mais de setenta idiomas nacionais, além dos dialetos regionais. Capacidade de ler e escrever estendida a todos e eletrificar o sistema produtivo foram dois enormes desafios interligados entre si com o objetivo de elevar o nível cultural do país e retirá-lo da escuridão. Isso foi conseguido pela revolução de outubro. Como vimos, eram indispensáveis educação e ciência modernas para eletrificar o país. A eletrificação, por sua vez, deveria mudar não apenas o padrão material da sociedade, mas também o seu padrão cultural, modernizando-o e contribuindo decisivamente para o sucesso da campanha de alfabetização. Pois, como alfabetizar um país às escuras?

Ao tratar do primeiro período pós-revolucionário na Rússia (1917-1930), no qual se inseriu a ação de Lênin, Franco Cambi realçou o "forte entusiasmo construtivo" e a "vontade de profunda renovação das instituições", marcado principalmente pela ação de Lounatcharski (1875-1933) e de Krupskaia (1869-1939). Nesse período, de acordo com ele, conviveram aspectos de ativismo pedagógico com os pressupostos marxistas de educação, principalmente no que diz respeito à proposição da escola única do trabalho. No entanto, a aplicação desse pressuposto basilar do marxismo, segundo ele, "raramente ultrapassou uma organização do trabalho artesanal (carpintaria ou culinária) e não foi possível conjugar realmente o trabalho intelectual com o produtivo, de modo a colocar em execução os princípios cardinais da teoria marxista" (CAMBI, 1999, p. 558).

As conquistas, de acordo com esse autor, foram conseguidas mais na batalha contra a velha escola, como a abolição do seu conteúdo religioso e nacionalista, e dos seus métodos de ensino. Ele registra, porém, o grande empenho na conjugação de instrução a trabalho, empenho visível em Krupskaia, que, tal como Lênin, além de levar em conta essa relação, se preocupava também em ampliar o horizonte cultural dos alunos. Ainda de acordo com Cambi, em 1936, já sob o "período totalitário" de Stalin, o ativismo pedagógico foi condenado e o trabalho nas escolas abolido. Nesse período, que durou até 1955 houve, todavia, uma forte expansão da escolaridade, melhoramento das estruturas da escola soviética e afirmação de vozes pedagógicas originais, como a de Makarenko. O

Revista HISTEDBR On-line, Campinas, número especial, p. 377-396, abr2011 - ISSN: 1676-2584 391 
autor ressalta, ainda, que, paralelamente aos regimes nazi-fascistas cujo resultado sobre a escola foi o enfraquecimento da cultura e sua forte ideologização, no socialismo soviético as tendências totalitárias também se manifestaram, embora, em seu conjunto, tenha sido mantida "uma escola de cultura (e não de ideologia apenas)" (CAMBI, 1999, p. 577).

Por sua vez, ao fazer um balanço dos problemas da instrução no socialismo, Manacorda afirma que "as dificuldades e contradições, retomadas e recuos, os passos à frente e atrás foram muitos na histórica da escola da União Soviética" (MANACORDA, 1989, p. 315). A teoria pedagógica socialista, segundo o autor, assumiu criticamente todas as instâncias da burguesia progressista:

\footnotetext{
"universalidade, laicidade, estatalidade, gratuidade, renovação cultural, assunção da temática do trabalho, como também a compreensão dos aspectos literário, intelectual, moral, físico, industrial e cívico. O que o marxismo acrescenta de próprio é, além de uma dura crítica à burguesia pela incapacidade de realizar esses seus programas, uma assunção mais radical e conseqüente dessas premissas e uma concepção mais orgânica da união instrução-trabalho na perspectiva oweniana [de Robert Owen] de uma formação total de todos os homens" (MANACORDA, 1989, p. 296).
}

Manacorda insiste nessa crítica e realça o elemento novo do marxismo, isto é, a relação instrução-trabalho (o grande tema da pedagogia moderna), que vai além do somatório de uma instrução tradicional mais uma capacidade profissional e tende a propor a formação de um homem omnilateral. Tudo isso em hipótese, lembra ele, "como proposição ideal, porque no socialismo real é extremamente árduo aplicar esse ideal, assim como é árduo no liberalismo e na democracia reais aplicar os ideais liberais e democráticos" (MANACORDA, 1989, p. 315).

Enfim, ao escolhermos o discurso de Lênin, transcrevendo-o na íntegra para este número especial da Revista HISTEDBR On-Line, tivemos em mente contribuir para o conhecimento de uma página quase ignorada da educação do século XX, inspirada e praticada segundo a concepção marxista. Durante um período de nossas vidas, estudamos e vivemos na União Soviética onde pudemos conhecer os resultados do esforço educativo empreendido por aquela sociedade desde a época de Lênin. Em grande parte esses resultados foram alcançados graças ao seu empenho e prestígio pessoal, fatores que, como vimos, foram determinantes para que em março de 1919, fosse aprovada a resolução que determinou instrução geral e politécnica gratuita e obrigatória para todas as crianças e adolescentes dos dois sexos, até os 17 anos de idade.

Tivemos a oportunidade de conhecer e julgar por nós mesmos os avanços e recuos da educação soviética construída desde a grande campanha pela alfabetização e pela eletrificação iniciada na época de Lênin. Conhecemos uma educação baseada no rigor e na valorização da cultura, embora tenhamos conhecido também as conseqüências da falta de liberdade política, um dos fatores explicativos da própria derrocada do "socialismo real". Conhecemos e participamos do trabalho voluntário nos sábados comunistas, herança da grande iniciativa que entusiasmou Lênin em 1919 e que na década de 1980 acontecia duas vezes por ano, ocasião em que comunistas e voluntários se dedicavam a um trabalho coletivo pelo "bem comum". Estudamos a obra de Lênin no Instituto de Ciências Sociais de Moscou, conhecemos os lugares onde ele viveu e atuou. Essa experiência singular, poucos anos antes do fim da União Soviética, nos proporcionou refletir sobre os desvios e erros que foram cometidos pelo Estado Soviético em nome do socialismo, descaminhos esses que não podem ser atribuídos unicamente a Stalin. Mas essa perspectiva crítica não 
nos afastou do marxismo e muito menos nos isenta de contribuir para o conhecimento de uma experiência e iniciativa raras pela educação no século XX. Uma educação que vislumbrava a construção de uma sociedade sem exploração, a formação integral do ser humano e fortemente ancorada nas condições materiais de sua época. Uma educação nascida daquelas condições e ao mesmo tempo pensada e praticada para superá-las.

Ao escrevermos este texto, talvez tenhamos querido, também, retribuir um pouco do que recebemos da educação soviética, além de reafirmar o nosso compromisso com o princípio da educação omnilateral. Pois, como escreveu Manacorda:

\begin{abstract}
"somente o homem quebrou os vínculos da unilateralidade natural e inventou sua possibilidade de tornar-se outro e melhor; e até omnilateral; considerando, outrossim, que esta possibilidade, dada apenas pela vida em sociedade, foi até agora negada pela própria sociedade à maioria, ou melhor, negada a todos em menor ou maior grau, o imperativo categórico da educação do homem pode ser assim enunciado: Apesar de o homem lhe parecer, por natureza e de fato, unilateral, eduque-o com todo empenho em qualquer parte do mundo para que se torne omnilateral" (MANACORDA, 1989, p. 361).
\end{abstract}

Se imperativos categóricos como este nunca mudaram a história, talvez eles sirvam para nos lembrar de olhar sempre para o alto e é por isso que, para encerrar, fazemos nossas as palavras de Manacorda.

\title{
Referências Bibliográficas
}

CAMBI, Franco. História da pedagogia. Tradução: Álvaro Lorencini. São Paulo: Editora UNESP, 1999.

CHESNAIS, Jean-Claude. A vingança do Terceiro Mundo. Tradução de A. Bastos. Rio de Janeiro: Espaço e Tempo, 1989.

ENGELS, Friedrich. Engels to C. Schmidt in Stuttgart. London, August 5, 1890. In: MARX, Karl; ENGELS, Friedrich. Selected correspondence. Translated by the Late I. Lasker. Moscow: Progress Publishers, 1965. p. 415-416.

FERREIRA Jr., Amarilio; BITTAR, Marisa. A concepção bolchevique da Revolução Socialista. Política Democrática, Brasília, p. 08-15, nov. 2007.

HOBSBAWM, Eric. Era dos extremos: o breve século XX (1914-1991). Tradução: Marcos Santarrita. São Paulo: Companhia das Letras, 1995.

LENINE, V. I. A que herança renunciamos?. In: Obras escolhidas. São Paulo: Editora Alfa-Omega, 1980. t. 1, p. 47-78.

LENINE, V. I. Segundo Congresso dos Sovietes, de deputados operários e soldados de toda a Rússia. . In: . Obras escolhidas. São Paulo: Editora Alfa-Omega, 1980. t. 2, p. 391407.

LENINE, V. I. As tarefas imediatas do poder Soviético. In: Obras escolhidas. São Paulo: Editora Alfa-Omega, 1980. t. 2, p. 557-587.

LENINE, V. I. Esboço do plano de trabalho científico-técnico. In: Obras escolhidas. São Paulo: Editora Alfa-Omega, 1980. t. 2, p. 589.

LENINE, V. I. VIII Congresso do PCR (b). In: Obras escolhidas. São Paulo: Editora Alfa-Omega, 1980. t. 3, p. 89-130. 
LENINE, V. I. Saudação aos operários húngaros. In: . Obras escolhidas. São Paulo: Editora Alfa-Omega, 1980. t. 3, p. 134- 137.

LENINE, V. I. Uma grande iniciativa. In: Alfa-Omega, 1980. t. 3, p. 143-160.

LENINE, V. I. Sobre o Estado. In: Obras escolhidas. São Paulo: Editora Omega, 1980. t. 3, p. 176-189.

. Obras escolhidas. São Paulo: Editora Alfa-

LENINE, V. I. Carta aos operários e camponeses a propósito da vitória sobre Koltchak. In: . Obras escolhidas. São Paulo: Editora Alfa-Omega, 1980. t. 3, p. 190-195.

LENINE, V. I. A economia e a política na época da ditadura do proletariado. In: . Obras escolhidas. São Paulo: Editora Alfa-Omega, 1980. t. 3, p. 198-209.

LENINE, V. I. Conversa com o correspondente do jornal americano The World, Lincoln Eire. In: Obras escolhidas. São Paulo: Editora Alfa-Omega, 1980. t. 3, p. 253-257.

LENINE, V. I. As tarefas das uniões da juventude. In: Obras escolhidas. São Paulo: Editora Alfa-Omega, 1980. t. 3, p. 386-397.

LENINE, V. I. Discurso na Conferência de toda a Rússia dos Comitês de Instrução Política das Secções de Gubérnia e Uezd da instrução pública. In: Obras escolhidas. São Paulo: Editora Alfa-Omega, 1980. t. 3, p. 400-407.

LENINE, V. I. VIII Congresso dos sovietes de toda a Rússia. In: Obras escolhidas. São Paulo: Editora Alfa-Omega, 1980. t. 3, p. 409-431.

LENINE, V. I. Sobre o plano econômico único. In: Obras escolhidas. São Paulo: Editora Alfa-Omega, 1980. t. 3, p. 463-469.

LENINE, V. I. X Congresso do PCR (b). In: Obras escolhidas. São Paulo: Editora Alfa-Omega, 1980. t. 3, p. 471-491.

LENINE, V. I. Sobre o imposto em espécie. In: Obras escolhidas. São Paulo: Editora Alfa-Omega, 1980. t. 3, p. 492-520.

LENINE, V. I. III Congresso da Internacional Comunista. In: São Paulo: Editora Alfa-Omega, 1980. t. 3, p. 525-543.

LENINE, V. I. Sobre o monopólio do comércio externo. In: Obras escolhidas. Paulo: Editora Alfa-Omega, 1980. t. 3, p. 611-617.

LÊNIN, V. I. Projeto de Estatuto do Partido Operário Social-Democrático Russo (POSDR). FELIPPE, WILIAM (Org.). Teoria e organização do partido: coletânea de textos de Lênin, Trotsky e Moreno. São Paulo: Editora José Luiz e Rosa Sundermann, 2006. p. 35-37.

LOUNATCHARSKI, A. Lénine tel qu'il fut. Moscou: Editions de l'Agence de presse Novosti, 1981.

MAKARENKO, A. S. Problemas da educação escolar: experiência do trabalho pedagógico (1920-1935). Tradução: Maria Pais. Moscovo: Edições Progresso, 1980.

MANACORDA, Mario Alighiero. História da educação: da Antigüidade aos nossos dias. Tradução: Gaetano Lo Mônaco. São Paulo: Cortez; Autores Associados, 1989.

MARTOV, Y. O. Projeto de Estatuto do Partido Operário Social-Democrático Russo (POSDR). FELIPPE, WILIAM (Org.). Teoria e organização do partido: coletânea de textos de Lênin, Trotsky e Moreno. São Paulo: Editora José Luiz e Rosa Sundermann, 2006. p. 39-44.

MARX, Karl; ENGELS, Friedrich. A ideologia alemã : crítica da filosofia alemã mais recente. $4^{\mathrm{a}}$ ed. Tradução: Conceição Jardim et al. Portugal: Editorial Presença; Brasil: Livraria Martins Fontes, 1980. v. I.

MARX, Karl. Teses sobre Feuerbach. In: MARX, Karl; ENGELS, Friedrich. Obras escolhidas em três tomos. Tradução: Álvaro Pina. Moscou: Edições Progresso; Lisboa: Edições “Avante!". 1982. t. I, p. 1-3. 
MARX, Karl. Instruções para os delegados do Conselho Geral Provisório. As diferentes questões. In: MARX, Karl; ENGELS, Friedrich. Obras escolhidas em três tomos. Tradução: José Barta Moura. Moscou: Edições Progresso; Lisboa: Edições “Avante!”. 1982. t. II, p. 79-89.

MARX, Karl; ENGELS, Friedrich. Manifesto do Partido Comunista. In: Obras escolhidas em três tomos. Tradução: Álvaro Pina. Lisboa: Edições "Avante!"; Moscovo: Edições Progresso, 1982. t. I, p. 106-136.

MARX, Karl. $O$ capital: crítica da economia política. Livro primeiro. O processo de produção do capital. Tradutor: Reginaldo Sant'Anna. São Paulo: DIFEL, 1984. v. I.

PONOMARIOV, B. N. (Org.). História do Partido Comunista da União Soviética. Tradução: Rui Facó; Josué Almeida; Almir Matos. Rio de Janeiro: Editora Vitória, 1961.

\section{Notas}

${ }^{1}$ Doutora em História Social (USP), professora titular de História e Filosofia da Educação da UFSCar e bolsista produtividade do CNPq (PQ 1D). Recebeu o Prêmio CAPES 2008 pela melhor tese orientada na área da Educação. Fundadora, em 2004, do GT/HISTEDBR/UFSCar. E-mail: bittar@ufscar.br

${ }^{2}$ Professor de História, Filosofia e Sociologia da Educação da UFSCar, com doutorado em História Social (USP). É bolsista produtividade (PQ2) do CNPq. E-mail: ferreira@ufscar.br

${ }^{3}$ Sobre a consolidação do poder bolchevique após 1920, consultar: HOBSBAWM. Era dos extremos, p. 70.

${ }^{4}$ Sobre as conseqüências da Primeira Guerra Mundial para a Revolução Russa de 1917, conferir: LENINE. Segundo Congresso dos Sovietes, de deputados operários e soldados de toda a Rússia, p. 396 et seq.

${ }^{5}$ Relativo ao papel desempenhado pelo Exército Vermelho na vitória sobre a intervenção armada patrocinada pelos países imperialistas, analisar: LENINE. Carta aos operários e camponeses a propósito da vitória sobre Koltchak, p. 190 et seq.

${ }^{6}$ Sobre as resoluções políticas que instituíram a NEP, verificar: LENINE. X Congresso do PCR (b), p. 474485.

${ }^{7}$ Quanto à introdução da propriedade privada de certos meios de produção e da adoção do livre comércio, ver: LENINE. Sobre o imposto em espécie, p. 493 et seq.

${ }^{8}$ Sobre o Estado como instrumento de poder nas mãos do proletariado para a edificação do socialismo, examinar: LENINE. Sobre o Estado, p. 176 et seq.

${ }^{9}$ Sobre o processo de industrialização da Rússia soviética, digno de nota são as seguintes obras: LENINE. As tarefas imediatas do poder Soviético, p. 557 et seq.; LENINE. VIII Congresso do PCR (b), p. 102.; LENINE. Sobre o monopólio do comércio externo, p. 611.; LENINE. III Congresso da Internacional Comunista, p. 525 et seq.

${ }^{10}$ O plano de eletrificação da Rússia Soviética encontra-se, entre outras, nas seguintes obras: LENINE. VIII Congresso dos sovietes de toda a Rússia, p. 428.; LENINE. Sobre o plano econômico único, p. 463 et seq.

${ }^{11}$ Sobre a situação social e econômica do campesinato após a Revolução de 1917, atentar para a seguinte obra: LENINE. A economia e a política na época da ditadura do proletariado, p. 205 et seq.

${ }^{12}$ A aplicação científica e tecnológica na produção econômica pode ser melhor compreendida em: LENINE. Esboço do plano de trabalho científico-técnico, p. 589.

${ }^{13}$ Sobre a posição de classe do campesinato frente à revolução socialista, observar: LENINE. A que herança renunciamos?, p. 57 et seq. 
${ }^{14} \mathrm{~A}$ posição bolchevique sobre a relação existente entre cultura e política encontra-se em: LENINE. Discurso na Conferência de toda a Rússia dos Comitês de Instrução Política das Secções de Gubérnia e Uezd da instrução pública, p. 400 et seq.

${ }^{15}$ Jean-Claude Chesnais, elaborando um panorama do nível da alfabetização em todos os países da Europa, assinala que no final do século XIX, "em última posição" estavam "a Europa Oriental (Balcãs, Polônia) e a Rússia, com uma proporção de iletrados entre 90 e 95\%" (CHESNAIS, 1989, p. 146). Ou seja, foi essa situação de extremo analfabetismo que a Revolução Russa herdou.

${ }^{16}$ Tradução do francês para o português elaborada pelos autores do artigo.

${ }^{17}$ Tradução do inglês para o português realizada pelos autores do artigo.

${ }^{18}$ Os dados e informações sobre a estrutura do ensino na época da Rússia czarista e dos primeiros anos do poder bolchevique que aparecem entre aspas nesse e nos parágrafos seguintes constam de nossas anotações das aulas de Economia Política ministradas pelo Prof. Dr. Oleg Tsukânov quando estudamos no Instituto de Ciências Sociais de Moscou na primeira metade da década de 1980.

${ }^{19}$ Anotações de aulas, conforme nota anterior.

${ }^{20}$ As propostas para o Estatuto do Partido Operário Social-Democrático Russo (POSDR), formuladas por Lênin e Martov, durante a realização do II Congresso do POSDR (Londres), encontram-se em: LÊNIN. Projeto de Estatuto do Partido Operário Social-Democrático Russo (POSDR), p. 35 et seq.; MARTOV. Projeto de Estatuto do Partido Operário Social-Democrático Russo (POSDR), p. 39 et seq.

${ }^{21}$ A partir de abril de 1917, o POSDR (bolchevique) passou a ser denominado Partido Comunista da Rússia (bolchevique). Depois, passou a ser o Partido Comunista da União das Repúblicas Socialistas Soviéticas (URSS).

Recebido em: $\quad$ 18/12/10

Aprovado em: $18 / 03 / 11$ 